\section{BBIOY starts recovery}

British Biotech (Oxford, UK) stands to receive $\$ 60$ million, thanks to a deal struck with Schering-Plough (Madison, NJ) in September giving Schering-Plough exclusive rights to develop and commercialize British Biotech's matrix metalloproteinase inhibitors (MMPIs) for the treatment of cancer. Schering-Plough will have rights to market the MMPIs worldwide except in Japan and some Asian territories. In addition to royalties, British Biotech could receive $\$ 60$ million in the form of a $\$ 4$ million up-front license fee, a $\$ 4$ million equity investment (British Biotech will issue 4.5 million new shares), and milestone payments. The company stock price rose almost $14 \%$ in response to the news, and analysts say the deal, which should reduce the company's burn rate, validates the new management and goes some way to restoring lost credibility (Nat. Biotechnol. 17, 624). Announcement of the deal followed release of phase III results for study 145 of Marimastat, an oral MMPI, in the treatment of patients with inoperable gastric cancer. Although the 369-patient trial failed to meet its primary endpoint, survival benefits strengthened over time and Marimastat was shown to slow tumor spread and prolong patient lives. Shares in British Biotech rose about $21 \%$ in response to the data, an encouraging development after two Marimastat failures earlier this year (Nat. Biotechnol. 17, 212).

\section{GMO panic affects drugs}

Axis Genetics (Cambridge, UK), a private biotechnology firm that makes vaccines in genetically modified (GM) plants, was put up for sale in September after failing to raise sufficient funds for the expansion of its R\&D program. Although Axis apparently secured $\mathfrak{E} 8.2$ million of the $£ 10$ million it required, investment conditions hostile to "green" biotechnology are thought to have been a factor in its investment shortfall. The company has made redundant half of its 50 staff members. Axis, which was formed in 1993, began US phase I trials of an oral hepatitis B vaccine in GM potatoes at the end of July, and is also developing vaccines against other infectious diseases and cancer. Investors, failing to distinguish drugs and food, seem to have been scared off by the hysteria currently surrounding GM crops in Europe. As a result, it is likely the company and its technology will be brought at a bargain price and developed outside the UK.

Business and Regulatory News written by Emma Dorey, Jeffrey Fox, John Hodgson, Asako Saegusa, and Ingeborg Spillmann-Fürst.

\section{US okays patent reform bill}

Early in August, the US House of Representatives voted overwhelmingly (376 to 43) to approve patent reform legislation. If passed by the Senate and signed by the president, the bill would extend the lifetime of patents based on the period an application spends under review by examiners in the US Patent and Trademark Office or when subject to appeals and interference rulings. Other pending legislation that also seeks to extend patent lifetimes targets the period that a patented product spends under regulatory review, typically by officials at the US Food and Drug Administration (Rockville, MD). The need for these reforms arises following adoption in 1994 of worldwide patent practices prescribed under the General Agreement on Trade and Tariffs, although those agreements specify patent terms of 20 years from filing rather than the earlier US patent term of 17 years from issuance. Because biotechnology patent applications tend to be very complex, that provision often penalizes biotech inventors, according to officials at the Biotechnology Industry Organization (BIO; Washington, DC), who say they welcome the legislative reforms.

\section{GM-free Japan}

Hoping to allay consumer fears, an increasing number of Japanese food manufacturers are abandoning the use of genetically modified (GM) ingredients in their products. One of the first companies to move toward nonGM ingredients was Kirin Beer (Tokyo), which announced in August that its beer would be GM-free by 2001 and that it would freeze its research into GM tomatoes. The move came in response to the government's decision in August to introduce mandatory labeling of food products containing detectable GM ingredients (Nat. Biotechnol. 17, 837, 1999). Kirin's announcement was followed by many others, including Kirin's competitor, Suntory (Tokyo), which has also declared that cornstarch used in its beer will be GM-free by 2001. Meanwhile, the Ministry of Agriculture, Forestry and Fisheries (MAFF; Tokyo) and the Ministry of Health and Welfare (MHW; Tokyo) are to tighten their respective safety regulations on GMOs. MAFF, which in June suspended the approval of Bt crops for agricultural purposes, is to launch a new project to examine potential risks of GM crops on the environment, while MHW, which is responsible for evaluating the safety of GM foods, plans to look into potential long-term risks of such food on human health.

\section{GM roundup}

- Marks \& Spencer (M\&S) has been caught with its pants down. The environmental campaigning organization Friends of the Earth (FoE) suggested to the British high street retailer that it will need to offer a choice of GM-free underwear to its clientele unless it is to suffer the kind of consumer backlash that savaged the food sector. FoE has implied that it will launch a "Frankenpants" campaign, drawing public attention to the fact that M\&S cannot guarantee that the cotton in its underwear is not derived from genetically modified (GM) plants. Although M\&S has not made any commitment on the Y-front, it has guaranteed that its Christmas turkeys will have been fattened on a GM-free diet. - Having deliberately scared the adult population over GM food, FoE is now using its "Kids Matters" supplement to recruit junior worriers to the cause. The "Frankenchow" campaign encourages kids to read labels and insist on GM-free pet food. Its misplaced campaign might be explained by FoE's clear belief in genetic determinism ("Genes contain all the information, for example, for how people look."). Or by the lack of judgment shown by its youth and education officer: Among the pets she admits to owning are a giant African land snail, a snake, and an iguananone of them native to her hometown of Stratford, London.

- John Jackson, the chairman of Britain's largest biotechnology company, Celltech Chiroscience, entered the GM crop fray when he expressed concerns about the effects of the crops on human health and the environment. Jackson is chairman of the Countryside Alliance, an organization that campaigns on behalf of rural dwellers and landowners. Among its contributions to the peace of the rural idyll are its campaigns supporting fox hunting with dogs, hare coursing (a live hare is chased across a set distance by a hunting dog), and ferreting.

- Pressure is building on the South African government from environmental scientists and activists to impose a moratorium on GM crop planting. A review of legislation commissioned by the environmental group, Biowatch South Africa, points to "anomalies and loopholes" in legislation that allow companies to monitor the environmental impact of their own plantings and to evade liability for damage.

- In mid August, Greenpeace reported net income of \$101 million and profits of \$7 million. 